\title{
Legalised non-consensual sterilisation - Eugenics put into practice before 1945, and the aftermath. Part 2: Europe.
}

\author{
Jean-Jacques Amy ${ }^{a}$ and Sam Rowlands ${ }^{b}$ \\ ${ }^{\text {a }}$ Faculty of Medicine \& Pharmacy, Vrije Universiteit Brussel, Brussels, Belgium; \\ ${ }^{\mathrm{b}}$ Faculty of Health \& Social Sciences, Bournemouth University, Bournemouth, UK.
}

Correspondence to: Prof. em. Jean-Jacques Amy, Florencestraat 62, B1050 Elsene, Belgium. Tel: +32 253760 15. E-mail: jeanjacques.amy@skynet.be

Word count : Title page: 64 ; Abstract: 263; Main text: 6,341 


\section{ABSTRACT}

This article deals with the nine European nations which legalised non-consensual sterilisation during the interwar years, thus completing the review, the first part of which was published in an earlier issue of this Journal. Like we did for North America, Japan and Mexico, countries concerned are addressed in chronological order, as practices in one of these influenced policies in others, involved later. For each, we assess the continuum of events up to the present time. The Swiss Canton of Vaud was the first political entity in Europe to introduce a law on compulsory sterilisation of people with intellectual disability, in 1928. Vaud's sterilisation Act aimed at safeguarding against the abusive performance of these procedures. The purpose of the laws enforced later in eight other European countries (all five Nordic countries; Germany and, after its annexation by the latter, Austria; Estonia) was, on the contrary, to effect the sterilisation of large numbers of people considered a burden to society. Between 1933 and 1939, from 360,00 to 400,000 residents (two thirds of whom were women) were compulsorily sterilised in Nazi Germany. In Sweden some 32,000 sterilisations carried out between 1935 and 1975 were involuntary. It might have been expected that after the Second World War ended and Nazi legislation was suspended in Germany and Austria, including that regulating coerced sterilisation, these inhuman practices would have been discontinued in all nations concerned; but this happened only decades later. More time still went by before the authorities in certain countries officially acknowledged the human rights violations committed, issued apologies, and developed reparation schemes for the victims' benefit.

\section{KEYWORDS}

Europe; eugenics; forced; history; involuntary; laws; non-consensual; sterilisation 


\section{Introduction}

This article completes the review of legalised non-consensual sterilisation the first part of which [1] was published in an earlier issue of this Journal. In that paper, we discussed at length the background of this gross transgression of human rights, endorsed and implemented in certain countries by the political authorities in place. All that is mentioned in the first section of the former article also applies to this one.

Part 1 of our historical review [1] went on with analysing the course of events in the first three countries which legalised non-consensual sterilisation (the USA, Japan and Canada) - and the State of Veracruz, in Mexico, which did likewise some years later. The present paper deals with the nine European countries which followed suit during the interwar years. Most involuntary sterilisations carried out before 1945 in Europe were involuntary and done on the grounds of punishment or eugenics. In 1945, after the collapse of the Third Reich, policies respectful of human rights were reinstated in Germany and Austria. But in the seven other European countries where forced sterilisation was legal and being practised - as happened in the USA, Japan and Canada - no changes occurred in this respect for a considerable length of time following the end of the Second World War. Nazi abuses and atrocities were insufficiently disclosed to- and hence known among the public to cause a universal repeal of laws authorising or ordering the compulsory sterilisation of certain subjects or population groups.

\section{Method}

The methodology used for this article is described in detail in our previous paper [1]. Again, countries are addressed in chronological order, as practices in one of these influenced policies in others, involved later. Like we did for North America and Japan [1], we assess the continuum of events in all nine European countries up to the present time. 


\section{Switzerland}

\subsection{Canton of Vaud}

Vaud was the first European jurisdiction to introduce a law on compulsory sterilisation of the mentally ill in 1928 [2]. The law aimed at preventing certain people from having 'degenerate' progeny, prejudicial to the existing order. Unlike the law enforced later in Nazi Germany, its purpose was not to effect the mass sterilisation of people with intellectual disability (ID) - or 'feeblemindedness' as it was then known as - but, on the contrary, to safeguard against the abusive performance of these procedures, as encountered in cantons with no similar law. The law concerned was repealed in 1985 [3]. The number of compulsory sterilisations done in Vaud (mainly on the grounds of ID) was low: the Vaudois Health Council granted 187 of the 378 received requests; the last operation took place in 1977. It is believed that fewer sterilisations were carried out because the law was in force than if it had not been. Those sterilised were mostly socially disadvantaged young women with mild to moderate ID; people with severe ID were interned in special institutions and hence considered not to require sterilisation [3]. The Director of a mental asylum in Lausanne expressed regret that the strictness of the law had disallowed « deserving » applications for sterilisation [4].

\subsection{All cantons}

Cantons other than Vaud had no law but preferred local guidelines or agreements between local authorities and doctors. In some cantons, mainly of Catholic persuasion, sterilisations were not done. The number of non-consensual sterilisations performed in Switzerland is unknown; most were done on unmarried, socially deprived women with children born out of wedlock, who were categorised as 'maladjusted', ‘sexually promiscuous', 'mentally disabled' or 'feebleminded'. Abortion requests were often granted only if the woman was simultaneously sterilised [5]. Some psychiatric institutions and hospitals recorded up to 400 annual sterilisations, most of which were coerced [6]. Non-consensual sterilisations were performed as recently as in the 1990s, in Neuchâtel and in Genève. 
The canton of Bern issued a Directive on sterilisation in 1931 which stipulated that a psychiatric examination and the consent of the person concerned were required. It condemned the referral for sterilisation of unmarried women who had behaved 'immorally' and restricted sterilisation to individuals with evident physical or mental disability. Eugenic or social indications alone were no longer accepted for sterilisation. This led psychiatrists of the Waldau Clinic to combine psychiatric, eugenic and social reasons so that women considered 'morally' or 'sexually deviant', dependent on welfare for future children, or with a family history of mental illness, epilepsy or suicide could still be sterilised. Between 1935 and 1953 around 25 such procedures were carried out yearly on their recommendation $[5,7]$.

In 1980, the Swiss Academy of Medical Sciences forbade the sterilisation of persons with severe ID. Nonetheless, Aargau (in 1987), Neuchâtel (in 1995), and Fribourg (in 1999) promulgated rules allowing sterilisation of people with such disability to enable them to freely enjoy a sexual life [3].

The Federal Council — considering that abusive sterilisation or castration had to be seen 'in the context of a constantly evolving society in which progress is born from the mistakes and injustices of the past' - first opposed the payment of compensation to victims, and Parliament had endorsed this view [8]. But, in response to a popular initiative launched in 2014, the Swiss Parliament accepted in 2016 a proposal for a one-off contribution of CHF 300 million to compensate victims of 'compulsory social measures' that were common practice until 1981. These included sending children to foster families, forced sterilisation, imprisonment, and obliging certain people to give their children up for adoption [9].

\section{Denmark}

In Nordic countries, unlike in the Third Reich, the Welfare State was eugenic policy's main impetus. A sense of social conformity, racist thinking, a desire to reduce public expenses, and a belief in 
science and social planning, all made compulsory sterilisation an attractive tool of policy. Programmes of coerced sterilisation were conceived, framed in legislative language, implemented - and covered up - even in these countries with liberal mores and compassionate social policies.

Denmark - in the absence of any organised eugenic lobby group - was the first European country to legalise castration of male 'delinquents', in 1929. In the five following years only 108 sterilisations were done, 88 of which were on women [10]. The law, revised in 1934, allowed forced surgical castration, but none was performed. Approximately 11,000 Danish people were sterilised between 1929 and 1967, at which time the law was repealed, and involuntary castration banned [11]. Until 1945, about $78 \%$ of those sterilised had ID, with twice as many women sterilised as men [12].

\section{Germany}

The eugenics movement in Germany was already operative in the late 19th century. Proponents claimed that improved medical care interfered with natural selection and enabled 'defective' individuals to procreate faster than normal ones. In 1927, the Kaiser Wilhelm Institute for Anthropology was founded in Berlin with substantial financial support from the American Rockefeller Foundation [13]. The Institute's director, anthropologist and eugenicist Eugen Fischer, was closely involved in the conception of Nazi eugenics policies. But, before 1932, eugenic schemes had not gained wide support. In 1932-1933 the State of Prussia advertised that it spent annually an eight-times greater sum for the upbringing of an educable but mentally ill child and a twelve-times greater one for that of a child born blind and deaf, compared to the average amount [14].

When the Nazis came to power in 1933, political opposition to eugenics was swept away. Three programmes were enforced: coerced sterilisation, 'euthanasia', and selective marriages [15]. On 14 July 1933, the Sterilisation Act, entitled 'Law for the Prevention of Hereditarily Diseased Offspring', was introduced; it was modelled on a US law drafted by Harry Laughlin, Superintendent of the US 
Eugenics Record Office. Under the 1933 law, people with ID and other mental and physical disabilities, considered to be 'untermenschen' (subhumans) were to be notified by their doctors.

Influential racial hygienists collaborated with the Nazi regime. An elaborate commentary on the law was written by the Swiss-born psychiatrist Ernst Rüdin, the doctor and SS Major General Arthur Gütt, and the lawyer and author of the so-called 'Nuremberg laws' Falk Ruttke. The Act instructed that the operation 'must be performed even against the will of the person to be sterilised. The attending surgeon must request assistance from the police, if needed. It is permissible to use direct force.' [14]. The programme was part of a set of measures allegedly intended to upgrade « racial hygiene » which became ever more radical; it started with the mass sterilisation of « genetically inferior » people and culminated in the near-annihilation of European Jewry [16].

More than 200 Hereditary Health Courts and Appellate Hereditary Health Courts were set up across Germany and, later, in annexed territories - each comprising two doctors and a district judge. The commonest grounds given for sterilisation were, in descending order of frequency, feeblemindedness, schizophrenia and epilepsy; other grounds were manic depression, hereditary deafness or blindness, Huntington's chorea, alcoholism and oral clefts. Behavioural reasons such as prostitution, homosexuality, vagrancy, were also invoked $[14,15,17,18]$. Tubal ligation, in women, and vasectomy, in men, were most frequently performed. Alternatively, women underwent a hysterectomy or 'radiation sterilisation' by means of radium or X-Rays, which resulted in castration [19]. Unlike the later T4 euthanasia programme, which was kept secret, the sterilisation programme was launched amid a blaze of publicity [16].

The Nazi regime kept precise records. During the first year of the Sterilisation Act, Hereditary Health Courts received 84,525 physician-initiated applications; they reached 64,499 decisions, 56,244 of which were in favour of the procedure [14]. At the mental hospital in Herborn, between 1934 and 1939, 620 men and 564 women were sterilised predominantly for ID. The law did not provide for sterilisation of 'aliens' such as Jews, Roma, and people of African descent so that the compulsory 
sterilisation of hundreds of mulatto children and youths in 1937 was illegal. 'Gypsies' ran a threefold greater risk of being sterilised than the general population, but this was because they were more frequently categorised as 'feebleminded' [20]. Overall, between 1933 and 1939, 360,000 to 375,000 (certain sources mention 400,000 [18]) people (two thirds of whom were women) were compulsorily sterilised. Individual, voluntary requests for sterilisation for contraceptive purposes were anathema when they concerned Aryans. For the latter, also pregnancy terminations on medical grounds were severely restricted, and harsh penalties applied for illegal abortions. An estimated 5,000-7,000 people died due to complications of forced sterilisations, $85-90 \%$ of whom were women. Others - mainly women - committed suicide. Many women deliberately got pregnant with a view to escaping sterilisation; this led in 1935 to an extension of the Sterilisation Act authorising abortions for eugenic reasons. These non-consensual abortions were mandatorily performed in conjunction with a sterilisation $[16,20]$. Resistance to the sterilisation programme by the medical profession came only from small groups of Marxist physicians. The Roman Catholic church was the sole body which strongly opposed the sterilisation law $[15,17,19]$.

\subsection{Nazi atrocities}

In concentration camps, mainly those at Dachau and Ravensbrück, sterilisation experiments were carried out. The victims were exposed to increasing doses of X-rays, sterilised surgically, or had sclerosants injected into uterus or testes [15,21].

\subsection{The world approves}

On 21 December 1933, the New York Times, in a leading article, estimated that '400 000 Germans [are] to be sterilized'. It went on to state that the programme would save the national economy the enormous costs of providing futile care for hereditary diseases. The author concluded by saying that 'In no country of the world is eugenics more active as an applied science than in Germany [...] Germany is the first of the great nations to make direct practical use of eugenics.' [14]. In 1934, the American Journal of Public Health published an article whose author [22] had an even greater fit of enthusiasm when he claimed that « if the objective of eliminating parenthood by those unfit is actually 
achieved in a thorough but legally and scientifically fair way [sic!], Germany will be the first modern nation to have reached a goal toward which other nations are just looking, or approaching at a snail's pace. » American eugenicists were wild about the German Sterilisation Act; one of them, Harry Laughlin, claimed that the latter was based on his own 'Model Sterilization Law'. In 1936, Laughlin was awarded an honorary doctorate for his contribution to eugenics by the University of Heidelberg [23].

\subsection{9: Implementation of the Aktion T4 euthanasia programme}

In 1939, the T4 euthanasia programme was instituted and eugenic sterilisations ceased [14].

Euthanasia killings ranged between 120,000 and 275,000; as many as $85 \%$ of the 'mental patients' of Germany were murdered [15].

\subsection{Compensation to victims of coercive sterilisation}

After the Nazis' defeat, the 1933 sterilisation law no longer applied, but it was abolished by the Bundestag only in 1988. In 2007 Parliament finally expressed regret and sympathy for the victims of compulsory sterilisation during the Third Reich. Compensation for the injuries sustained was a contentious issue, particularly in relation to the extent to which these unfortunate people could be considered victims of Nazi molestation. In 1980 a compensation fund was created, but the criteria to be taken into consideration were manifestly unfair [20]. From 1988 onwards, those forcefully sterilised under the Nazi regime were granted a monthly allowance (amounting to $291 €$ in 2015). According to the German Government, on 27 February 2012, 13,816 forcibly sterilised individuals had received a lump-sum and 9,604 others, a monthly allowance [24].

\section{Norway}

Psychiatric patients were being sterilised in Norway already in the 1920s. The Norwegian law of 1934 allowed not only sterilisation on genetic, social and economic grounds [10] but also castration of sexual offenders, with the aim of preventing further sexual assaults [25]. Sterilisations within the 
confines of the Act needed approval from the Health Director or a Central sterilisation council; others, not regulated by law and hence not requiring permission, could be done on medical grounds. The latter were not registered systematically, and their number is unknown. The law remained in force until 1977. By then, 28,000 women and 16,500 men had been sterilised; 2,123 operations concerned minors, insane or people with ID. Applications regarding people categorised as such were increasingly ignored from the 1950s onwards. Although the 1934 Act prohibited sterilisation on racial or ethnic grounds, travellers (among whom many were Roma) were sterilised, often while in the custody of the State-run Mission for the Homeless; $37 \%$ of those in the Svanviken Work Colony in Nordmøre were sterilised between 1949 and 1970 [20]. At the turn of the millennium, 15 to 20 people with ID were still being sterilised yearly, 75\% for feeblemindedness. Haave, in 2000, estimated that, between 1934 and 1977, as many as 42,000 women could have been sterilised on medical grounds - thus outside the law - and that non-consensual sterilisations were far more frequent than stated in official documents $[20]$.

The original Act did not elicit much professional disagreement nor concern in the population except for criticisms aired by those who considered the requirements for sterilisation without consent to be too strict. Extreme eugenic views were expressed, but during the interwar years, Norwegian geneticists increasingly opposed the popular eugenics movement, arguing that research had disproved both a noticeable degeneration of the genetic material in the population and any favourable effects of the proposed eugenic policies. In two guidelines to the Act promulgated in 1938 and 1950, the requirements for involuntary sterilisation were made more stringent. From 1950 onwards, only individuals with severe and/or permanent ID, incapable of discerning what the procedure implied, and certain chronically 'insane' people could be sterilised without consenting to it. In the 1990s, long after revocation of the Act, forced sterilisation became a topic of public debate; by then, many people considered sterilisation of individuals with ID or mental disease as morally reprehensible [25]. In 1998 the Norwegian government publicly apologised to the victims of the former eugenic policies. Individual compensation defined by the Parliament in 2005 was restricted to unlawful sterilisations $[20]$. 
In July 1942, under the German occupation, the collaborating Norwegian government, allegedly for 'protecting the Norwegian race', passed a new sterilisation Act partly modelled on the 1933 Nazi law, which allowed physical coercion. This Act was in force from 29 December 1942 until the end of the occupation, on 8 May 1945. There were 570 applications under the 1942 law; 540 were approved and 502 carried out ( 419 women and 83 men). Professionals making applications were mostly psychiatrists. Individuals sterilised were mainly those with ID, followed by the mentally ill. However, the scale of sterilisations between 1942 and 1945 was not great in comparison to the population of potential recipients $[25,26]$.

\section{Sweden}

Swedish laws, enacted in 1934 and in 1941, permitted 'legally incapable' people to be sterilised. The three indications were: eugenic, social and medical. There was no requirement for consent from the individual concerned, no Board and no court hearing. In the 1940s, such compulsory sterilisations were done on so-called 'inferior' members of society considered feebleminded or otherwise unfit. This policy, in force between 1935 and 1975, had been endorsed by all Swedish parties except the Communist Party, which consistently opposed it. The law aimed at stopping the spread of hereditary disease and at preventing people, considered unfit to become parents, from procreating. Ostracism and covert racism were determinants of the measures taken against vagrants, but people with other 'deviant' behaviours were sterilised as well: Roma, prisoners, people with ID, and women who had sought to terminate their pregnancies. The law was amended in 1976 to require freely given consent for sterilisation; since then, the principle of free will has been so rigorously applied that sterilisation of the 'legally incapable' is no longer allowed [25].

There were 62,888 sterilisations between 1935 and 1975, with a peak at 2,351 in 1949; these numbers are high for a country of 7 million inhabitants at the time. From the 1950s onwards, sterilisations were linked with abortions: the latter were authorised only if a sterilisation was agreed to. 
The Swedish medical profession was split on the acceptability of eugenic sterilisations [10,27]. Public opinion was alerted to the issue when the Swedish newspaper Dagens Nyheter, in 1997, and Maija Runcis, in her doctoral thesis, in 1999, revealed that thousands of Swedes had been involuntarily sterilised [28]. In response to the media frenzy this caused, with a ripple effect in other countries, the Swedish Government set up a Commission to investigate this matter. The latter reported in 2000 that some 32,000 of the close to 63,000 operations carried out between 1935 and 1975 were involuntary. Of the cases that could be classified, almost 6,000 sterilisations were coerced, 15,000 had definite coercive elements (e.g., conditional on having an abortion or being released from an institution), and in a further 6,000 a degree of pressure or persuasion had been applied [29].

A state commission concluded that those sterilised without their consent should receive reparations [6]. In 1999 a new law provided compensation to sterilised people who met certain criteria - such as never having signed an authorisation for sterilisation, having been an inmate, or having been subjected to undue pressure. Compensation claims were received until December 2002. Between 1999 and 2002, about 1,700 individuals received compensation of 175,000 Swedish Krona each. An apology was made specifically to 'travellers' who had been sterilised [24,27].

\section{Finland}

In the early 20th century, eugenics was promoted in Finland with a view to fostering greater political and social influence for the Swedish-speaking minority. The census of citizens with ID, held in 1906, revealed that their number was three times greater than expected. In 1912, it was proposed that criminals, the feebleminded, epileptics, alcoholics, and the chronically insane be sterilised. Sterilisation was claimed to be humane, to stop the transmission of these conditions, to allow patients confined in institutions to be safely discharged home, and to reduce public spending. As in other Scandinavian countries there was a strong public feeling that the 'degenerate' were more promiscuous, 
had more children and threatened social order. Because sex crime was becoming more frequent, women's groups called on the authorities to have sexual offenders castrated.

Sterilisation had been practised occasionally before a sterilisation law was introduced in Finland in 1935. The law drafted in 1929 allowed the procedure to be performed on 'mentally retarded', the 'mentally ill', and epileptics, provided the person or the person's guardian consented to it and the procedure was approved by the National Board of Health. The draft also advocated that, after sterilisation, marriage be permitted. Another item in the bill concerned castration of sex offenders. Legalisation of sterilisation became more appealing after Germany enacted its Sterilisation Act in July 1933. Along the lines of the German Law, two extra clauses were added to the draft. The first one stated that - in particular cases and with the approval of the National Board of Health - one could be sterilised even without having voluntarily consented to this [30,31]; the second clause stipulated that individuals with hereditary illness who already had children could be sterilised if there was evidence of child neglect or abuse. Parliament removed epileptics from the target group (epileptics were initially excluded in Germany as well because some were former soldiers who had sustained brain injuries during the war) and approved the remainder of the proposal by a large majority.

In the 1930s, eugenic sterilisation was considered by many the most rational and humanitarian approach, serving the interests of both the individual concerned and society. Yet, members of the clergy claimed that sterilisation, by lifting the deterrent of pregnancy, could pave the way to sexual debauchery. The newspaper Tulenkantajat stated that the Sterilisation Law prioritised the state over the individual; that - as in Germany - it might serve to forward a political agenda; and that it would lead to excesses in its application. Other criticisms referred to (i) the insufficient understanding of the mechanisms involved in the transmission of ailments it aimed at eradicating; (ii) the violation of human rights its application entailed; and (iii) the risk of complications, including mortality, associated with the operations. 
In that population of less than four million, 996 sterilisations were done under the 1935 Eugenic sterilisation Law between 1935 and 1950. In 1950, the Act was replaced by a harsher one; recent events in Germany did not deter the passage of the law. Only Japan, in 1948, and Finland, in 1950, passed new eugenic sterilisation laws in the postwar period. Sterilisation numbers in Denmark, Norway and Sweden started to drop in 1950, but swelled in Finland, possibly because there, sterilisation was a means of legally obtaining an abortion. After the war, 11,000 eugenic sterilisations were carried out [30,31]. Forced sterilisation ceased by the end of the 1960s.

\section{Estonia}

The Estonian sterilisation law of 1937 permitted sterilisation on grounds of insanity, physical disability and severe epilepsy. Few sterilisations were done: 21 in 1937 and 20 in 1938. The current Sterilisation Act stipulates that 'sterilisation of adults with restricted active legal capacity may be allowed by a court ruling' only if one of the following conditions is fulfilled [32]:

- pregnancy is dangerous for the woman's health,

- all other contraceptive methods are contraindicated,

- there is a high risk of delivering a child with severe mental or physical disability,

- $\quad$ health problems prevent the person from raising a child.

Sterilisation of minors is forbidden [33].

\section{Iceland}

In Iceland, the law promulgated in 1938 allowed sterilisation and abortion of the 'feebleminded'. Sterilisation of people with ID was widely practised between 1965 and 1975 when the law was repealed, although the procedure was still performed to some extent thereafter [34]. Nine men and 120 women with ID are recorded as having been compulsorily sterilised [35].

\section{Austria}


The Nazi 'Law for the Prevention of Genetically Diseased Offspring' was enforced in Austria in 1940, two years after the country's annexation ('Anschluss') by Germany. The first coerced sterilisations were done in the spring of 1940. In Styria (south-eastern and central Austria), 16 doctors, working in 13 care facilities, were designated to perform these procedures [36]. Of the 360,000 to 400,000 people sterilised under the Nazis, about 6,000 were probably Austrians.

After annexation by Germany, deaf people in Austria faced forced sterilisation, internment, deportation and euthanasia; pregnant deaf women were coerced to obtain an abortion. To hide the congenital nature of the hearing impairment, relatives claimed that it resulted from falls or blows to the head. It is unknown how many deaf people were compulsorily sterilised. They were only officially granted the status of victims of Nazism in 1995, though the label had existed since 1945.

Austrian Nazi court rulings calling for people with hereditary disabilities to be sterilised were never officially reversed [37] but people forcibly sterilised after the 'Anschluss' could receive compensation under the Victims' Pension Law enacted in July 1947 and benefit from reduced fees for social insurance and studies [38].

Experts stated in 1997 that Austrian women with ID were still being sterilised against their will but added that no official statistics were available. In 2005, one such woman sued her parents and health officials. Her father had asked that she be sterilised on the grounds of 'mental retardation' [39].

\section{Discussion}

\subsection{Background}

Forced sterilisation cannot be dissociated from eugenics. The latter term was coined in 1883 by the English scientist Francis Galton, a cousin of Charles Darwin. Galton theorised that mankind might in part direct its own evolution. In his treatise 'Hereditary Genius', published in 1869, he suggested that 'a highly gifted race of men' could be obtained by means of 'judicious marriages during several consecutive generations' [40]. He considered that eugenics embodied the new commitment which 
should be met to enhance the further evolution of the 'human race' [41]. From 1911 onwards, the chair of eugenics at University College, London University, was occupied by Karl Pearson, an accomplished mathematician who contributed significantly to creating the science of biometry. Professor Pearson was convinced that the high birth rate of the lower classes constituted a threat to civilisation and that the 'higher' races should supplant the 'lower'. This doctrine - which soon developed into a social movement - aimed at reducing the proportion of people with lesser than average genetic endowment and, by extension, of all individuals considered a burden to society. It gave solid backing to those believing in racial and class superiorities [42]. Eugenics rapidly became popular, it swept over the industrialised world, reached its acme in the 1930s, and - in various countries - remained influential until several decades after World War Two had ended. Somehow, Pearson was morally responsible for the radicalisation of eugenics theses in the USA which led to gross human rights transgressions, and for easing the way for the implementation by the Nazi regime of harsh sterilisation policies in 1933, and of the even more dreadful T4 euthanasia programme in 1939. Amazingly, despite London since the 1880s having been the cradle of eugenics' ideology, no sterilisation law came into being in the UK; a different approach was resorted to for preventing ‘undesirable stock' from procreating. The Feeble-Minded Control Bill was introduced in 1912 in the House of Commons. It rejected compulsory sterilisation but provided for registration and segregation and gave the Home Secretary the power to commit any person without ID but 'whose circumstances appeared to warrant his inclusion.' The Archbishops of Canterbury and York, and writer H.G. Wells supported the Bill whereas G.K. Chesterton led a public campaign against it. Being much concerned by the high cost of internment, Winston Churchill favoured compulsory sterilisation which he described as a 'simple surgical operation so the inferior could be permitted freely in the world without causing much inconvenience to others.' [43].

\section{2 Findings and interpretation}

Our prior article [1] and this one bring important themes to light. 
By 1940, sterilisation laws had been passed in 13 countries spread over three continents, all of which provided for the compulsory sterilisation of people thought to be insane, to present an ID, or to have certain chronic ailments. Some Acts applied to habitual criminals and sexual 'perverts' as well. In most instances indications were eugenic, but the authorities in place tacitly permitted sterilisation for social reasons also. In all these countries but one (the State of Veracruz, in Mexico), the law was applied - to large numbers of citizens, as in Nazi Germany, or with moderation and with a view to prevent excesses, as in the Swiss canton of Vaud.

Well into the second half of the 20th century, there were undeniable similarities between sterilisation policies of supposedly democratic countries (e.g., the USA, Canada, Sweden, Finland) and those which had been implemented by the totalitarian regimes in Japan and Nazi Germany. In neither setting did physicians refuse their collaboration; on the contrary, they often provided active support.

Likewise, few organisations objected, in the countries concerned. Pope Pius XII, in a letter addressed in December 1935 to cardinal Schulte of Cologne, had declared that - with regard to the position of the Church towards the Third Reich's coerced sterilisation programme - a formal protest from the Holy Seal would have detrimental effects for the German episcopate [44]. Yet, the Catholic Church, for reasons of doctrine pertaining to human reproduction, would systematically oppose sterilisation policies. This may explain why - except for the State of Veracruz, the Third Reich (with one third of all Germans reclaiming their Catholic roots), and Austria (after the Anschluss) - in areas where the Catholic faith was predominant, no such laws were promulgated, and non-consensual sterilisation was at most only sporadically carried out. In the UK, the Labour Party, possibly on its own, succeeded in preventing the approval of a sterilisation law by Parliament, in the mid-1930s. In Sweden, the Communist Party was the only political group that persistently opposed the sterilisation law in force between 1935 and 1975 .

After the defeat of the Axis powers, in 1945, Nazi legislation was abrogated and sterilisation under duress put to an end in Germany and Austria. It is unsettling that - despite the knowledge gained on the despicable transgressions of human rights under the Nazi regime - the other countries or regions 
amended or repealed their sterilisation laws only decades later. In the 1960s and the early 1970s, when the Vietnam war was raging, the Netherlands and the Scandinavian countries were considered by many to be havens of democracy and lighthouses of political ethics, and yet all of Scandinavia ran eugenic sterilisation programmes at the time. The greatest number of people were compulsorily sterilised in Sweden, the least in Norway.

Reparations were mostly delayed for a considerable length of time - authorities often moved only after the victims of compulsory sterilisation went public with their stories. Over time, apologies and compensation came in North America and in Europe. Victims in Japan first went public and sued the government as late as in January and February 2018.

\subsection{Strengths and weaknesses of the study}

To the best of our knowledge, our two papers are the first to analyse the continuum of events in all 13 countries which enforced compulsory sterilisation policies before World War Two. Due to their chronological structure, the articles highlight how much forerunners in this domain - in particular, the USA and, later, Nazi Germany - influenced the subsequent shaping or modification of sterilisation laws in certain other nations (e.g., Sweden, Finland). We stressed how frighteningly similar the eugenics ideologies and the sterilisation Acts were in the USA and Hitler's Germany.

Our study's main limitation pertains to the nature of the sources we perused for collating information, namely, secondary sources (the literature in three languages we could access) instead of primary ones (registers of non-consensual sterilisation, where still in existence). In all likelihood, the numbers of procedures actually done must have exceeded those we have mentioned,

\subsection{Relevance of the findings: implications for clinicians and policymakers}

Particular attention must be given to the conveying of ethical values during the training of health personnel and social workers. This should include participative discussions of topics such as basic 
human rights and their transgressions, informed consent vs. coercion, public health provision in democratic vs. totalitarian regimes.

\subsection{Unanswered questions and future research}

The frequency of 'sporadic' cases in countries where non-consensual sterilisation was not legally authorised should be investigated.

\section{Disclosure statement}

The authors report no conflicts of interest. The authors alone are responsible for the content and the writing of the article. 


\section{References}

[1] Amy JJ, Rowlands S. Legalised non-consensual sterilisation - Eugenics put into practice before 1945, and the aftermath. Part 1: USA, Japan, Canada and Mexico. Eur J Contracept Reprod Health Care. 2018; in press..

[2] Gasser J, Heller G. Etude de cas: les débuts de la stérilisation légale des malades mentaux dans le canton de Vaud. Gesnerus 1997;54:242-250.

[3] Heller G, Jeanmonod G, Gasser J, Dumoulin JF. Rejetées, rebelles, mal adaptées: débats sur l'eugénisme: pratiques de la stérilisation non volontaire en Suisse romande au XXe siècle. ChêneBourg/Geneva: Georg Editeur; 2002.

[4] Jeanmonod G, Gasser J, Heller G. Historical aspects of psychiatry in French-speaking Switzerland during World War II. Int J Mental Health. 2007;36:26-44.

[5] Mottier V. Eugenics and the State: Policymaking in comparative perspective. In: Bashford A, Levine P (Eds.), The Oxford handbook of the history of Eugenics. New York: Oxford University Press; 2010: 134-153.

[6] SSHRCC. Eugenics Archive. Ottawa: Social Sciences and Humanities Research Council of Canada; 2017.

[7] Swiss National Council, Committee for Legal Affairs. Initiative parlementaire Stérilisations forcées - Dédommagement des victimes [von Felten]. 2003. [cited 2017 Aug 17]. Available from: https://www.admin.ch/opc/fr/federal-gazette/2003/5753.pdf 
[8] United Nations, Human Rights Committee. Consideration of reports submitted by State parties under article 40 of the covenant - Third periodic report: Switzerland. 2007. [cited 2017 Aug 17]. Available from: http://repository.un.org/bitstream/handle/11176/268967/CCPR_C_CHE_3EN.pdf?sequence=1\&isAllowed=y

[9] Anonymous. Compulsory social measures: the long way to rehabilitation. 2017. [cited 2017 Aug 17]. Available from: http://www.humanrights.ch/en/switzerland/internalaffairs/protection/miscellaneous/compulsory-social-measures-long-rehabilitation

[10] Drouard A. Concerning eugenics in Scandinavia. An evaluation of recent research. Population 1999;11:261-270.

[11] Jütte R. Contraception: a history. Cambridge: Polity Press; 2008.

[12] Hansen BS. Something rotten in the State of Denmark: eugenics and the ascent of the Welfare State. Helsinki: University of Helsinki; 2006.

[13] Schafft GE. From racism to genocide: Anthropology in the Third Reich. Urbana and Chicago: University of Illinois Press; 2004:48-54.

[14] Hanauske-Abel HM. Not a slippery slope of sudden subversion: German medicine and National Socialism in 1933. BMJ. 1996;313:1453-1463.

[15] Wyszinski DF. Fifty years after the Nuremberg Nazi doctors' trial: reviewing how the laws of the Third Reich applied to individuals with oral clefts. Plast Reconstr Surg. 1998;101:519-527.

[16] Bock G. Antinatalism, maternity and paternity in National Socialist racism. In: Crew DF (Ed.), Nazism and German society 1933-1945. London: Routledge; 2002: 110-140. 
[17] Sofair AN, Kaldjian LC. Eugenic sterilization and a qualified Nazi analogy: the United States and Germany, 1930-1945. Ann Intern Med. 2000;132:312-319.

[18] Proctor RN. Racial hygiene: medicine under the Nazis. Cambridge, MS: Harvard University Press; 1988.

[19] Stauber M, Kindermann G. Über inhumane Praktiken der Frauenheilkunde im Nationalsozialismus und ihren Opfer. Geburtsh Frauenheilk 1994;54:479-488.

[20] Braun K, Hermann SL, Brekke OA. Sterilization policies, moral rehabilitation and the politics of amends. Critical Policy Stud. 2014;8:203-226.

[21] Trombley S. The right to reproduce: a history of coercive sterilization. London: Weidenfeld \& Nicolson; 1988.

[22] Peter WW. Germany's sterilization program. Am J Public Health. 1934;24:187-191.

[23] Jackson JP, Jr, Weidman NM. Race, racism and science - Social impact and interaction. New Brunswick, NJ: Rutgers University Press; 204:123.

[24] ERRC. Anna Maderová v Czech Republic: Third-Party Intervention. European Court of Human Rights. 2015. [cited 2017 Aug 17]. Available from: http://www.errc.org/article/mad\%C4\%95rova-vczech-republic-third-party-intervention-pending/4436

[25] Haavie S. Sterilization in Norway - a dark chapter? Eurozine 9 April 2003. [cited 2017 Aug 17]. Availble from: http://www.eurozine.com/sterilization-in-norway-a-dark-chapter/ 
[26] Haave P. Sterilisation under the Swastika: the case of Norway. Int J Mental Health. 2007;36:4557.

[27] Lynöe N. Race enhancement through sterilisation: Swedish experiences. Int J Mental Health. 2007;36:17-25.

[28] Gerodetti N. Whose reparation claims count? Gender, history and (in)justice. Aust Feminist Legal J. 2016;42;97-118.

[29] Ramsay S. Enforced sterilisations in Sweden confirmed. Lancet 2000;355:1252.

[30] Hemminki E, Rasimus A, Forssas E. Sterilization in Finland: from eugenics to contraception. Soc Sci Med. 1997;45:1875-1884.

[31] Seeman MV. Sterilisation of the mentally ill during the years of World War II in Finland. Int J Ment Health. 2007;36:58-66.

[32] Government of Estonia. Response of Estonia to the questionnaire for the preparation of the OHCHR analytical study on Violence against women and disability. 2011. [cited 2017 Aug 17]. Available from: http://www.ohchr.org/Documents/Issues/Women/WRGS/GirlsAndDisability/Governments/Estonia.pd f

[33] Kalling K. The application of eugenics in Estonia 1918-1940. In: Felder BM, Weindling PJ (Eds), Baltic eugenics: Bio-politics, race and nation in interwar Estonia, Latvia and Lithuania 1918 - 1940. Amsterdam: Rodopi; 2013: 49-82. 
[34] Stefánsdóttir GV. Sterilisation and women with intellectual disability in Iceland. J Intellect Dev Disabil. 2014;39:188-197.

[35] Stefánsdóttir GV, Hreinsdóttir EE. Sterilization, intellectual disability, and some ethical and methodological challenges: It shouldn't be a secret. Ethics Soc Welf. 2013;7:302-308.

[36] Czarnowski G, Hildebrandt S. Research on the boundary between life and death - Coercive experiments on pregnant women and their fetuses during National Socialism. In: Weindling P (Ed.), From clinic to concentration camp - Reassessing Nazi medical and racial research, 1933-1945. London and New York: Routledge; 2017:73-99.

[37] AFP/Expatica. Euthanasia, sterilisation: Austria faces Nazis' treatment of the deaf. 2009. [cited 2017 Aug 17]. Available from: https://www.expatica.com/de/news/Euthanasia-sterilisation-Austriafaces-Nazis-treatment-of-the-deaf_165877.html

[38] Stejskalová M, Szilvási M. Sterilisation and its consequences for Romani women in the Czech Republic [1966-2016]. Budapest: European Roma Rights Centre; 2016.

[39] Leidig M. Austrian woman sues over sterilisation without consent. BMJ. 2000;331:1162-1163.

[40] Galton F. Hereditary genius - An inquiry into its laws and consequences, $2^{\text {nd }}$ edn. London: Macmillan and Co.; 1892:1. [cited 2018 Mar 14]. Available from: http://galton.org/books/hereditarygenius/text/pdf/galton-1869-genius-v4.pdf

[41] Galton F. Inquiries into human faculty and its development, $2^{\text {nd }}$ edn. London: J. M. Dent \& Co. (Everyman); 1907:220. [cited 2018 Mar 14]. Available from: http://galton.org/books/humanfaculty/text/galton-1883-human-faculty-v4.pdf 
[42] Osborn FH. Eugenics. In: The New Encyclopaedia Britannica, 15th edn., Macropaedia, vol. 6. Chicago, IL: Encyclopaedia Britannica, Inc.; 1979:1023-1024.

[43] Gilbert M. Churchill and eugenics. The International Churchill Society. [cited 2018 Mar 15]. Available from: https://www.winstonchurchill.org/publications/finest-hour-extras/churchill-andeugenics-1/

[44] Archivo segreto vaticano. Affari ecclesiastici straordinari, 'Germania', 1935, Pos. 692, fasc. 260, 4-8, ff. 38. Quoted in Verhofstadt D. Pius XII en de vernietiging van de Joden. Antwerp/Amsterdam: Houtekiet/Atlas; 2008:181,473. 